\title{
In vitro Evaluation of Seaweed Gracilaria verrucosa for Cytotoxic Activity against Cervical HeLa Cells
}

\author{
Micheylla Kusumaning Dewi ${ }^{1}$, Ade Arsianti ${ }^{2,3 *}$, Cut Raisya Zahira Zagloel ${ }^{1}$, Yully Astika Nugrahayning Aziza', \\ Kartika Dwi Kurniasari ${ }^{1}$, Baiq Kirana Dyahningrum Mandasari', Riathul Masita ${ }^{1}$, Futihati Ruhama Zulfa', \\ Norma Nur Azizah ${ }^{3}$, Rista Putrianingsih²
}

\section{Micheylla Kusumaning Dewi ${ }^{1}$, Ade Arsianti ${ }^{2,3^{*}}$, Cut Raisya Zahira Zagloel', Yully Astika Nugrahayning Aziza', Kartika Dwi Kurniasari', Baiq Kirana Dyahningrum Mandasari', Riathul Masita', Futihati Ruhama Zulfa', Norma Nur Azizah ${ }^{3}$, Rista Putrianingsih $^{2}$}

'Medical Student, Department of Medical Chemistry, Faculty of Medicine University of Indonesia, Depok, INDONESIA. 2Department of Medical Chemistry, Faculty of Medicine, University of Indonesia, Depok, INDONESIA.

${ }^{3}$ Drug Development Research Cluster, Drug Discovery Division, Indonesia Medical Education and Research Institute (IMERI), Faculty of Medicine, University of Indonesia, Jalan Salemba Raya 6 Jakarta 10430, INDONESIA.

\section{Correspondence}

Dr. Ade Arsianti

Drug Development Research Cluster, Indonesia Medical Education and Research Institute (IMERI), Faculty of Medicine, University of Indonesia, Jalan Salemba Raya 6 Jakarta 10430, INDONESIA.

Phone no : +6281312581253

E-mail: arsi_ade2002@yahoo.com

\section{History}

- Submission Date: 03-04-2018;

- Review completed: 22-05-2018;

- Accepted Date: 11-07-2018

\section{DOI : 10.5530/pj.2018.5.171}

Article Available online

http://www.phcogj.com/v10/i5

\section{Copyright}

(C) 2018 Phcog.Net. This is an openaccess article distributed under the terms of the Creative Commons Attribution 4.0 International license.

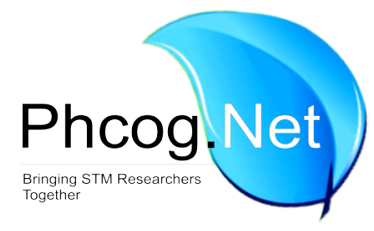

\begin{abstract}
Background: Seaweed macroalgae of Gracilaria verrucosa has been known to have a potent anticancer activity, however the cytotoxicity against cervical cancer has not been explored further. Objective: This study aims to utilize Indonesia's marine resource which is focused on seaweed macroalgae G. verrucosa as a future anti-cervical cancer agent. Materials and Method: Seaweed G. verrucosa originated from Labuan Aji beach, Nusa Tenggara Barat, Indonesia, extracted, macerated, and fractionated into four organic solvents of different polarity, consisting of hexane, ethyl acetate, chloroform and ethanol. Then, the macroalgae extracts are diluted into 8 different concentrations. Afterwards, in vitro anticancer activity evaluation of hexane, ethyl acetate, chloroform and ethanol extracts of G. verrucosa against cervical HeLa cells were conducted by MTT cell proliferation assay. Triplo mechanism is also applied in this study to increase the accuracy of the results. The anticancer activity is measured using $I C_{50}$ value. Results: The four concentrated extracts G. verrucosa showed cytotoxicity against cervical HeLa cells. The greatest anticancer activity is depicted by hexane extract with an $\mathrm{IC}_{50}$ of 14.94 $\mu \mathrm{g} / \mathrm{mL}$, followed by chloroform $\left(\mathrm{IC}_{50} 15.74 \mu \mathrm{g} / \mathrm{mL}\right)$, ethyl acetate $\left(\mathrm{IC}_{50} 16.18 \mu \mathrm{g} / \mathrm{mL}\right)$, and ethanol $\left(I C_{50} 19.43 \mu \mathrm{g} / \mathrm{mL}\right)$. Conclusion: Our results clearly indicate that hexane, ethanol, chloroform, and ethyl acetate extracts of seaweed $G$. verrucosa can be further developed to be anti-cervical cancer agents, with hexane extract displaying the greatest cytotoxic effect.
\end{abstract}

Key words: Gracillaria verrucosa, Cytotoxicity, HeLa cervical cancer cells, MTT assay, IC value,

\section{INTRODUCTION}

Cervical cancer is a type of cancer that arises from the cervical surface epithelium, located on the opening of the uterus. At early stages of cervical cancer, this disease is usually asymptomatic. If symptoms do occur, the most common manifestation would be unusual vaginal bleeding. ${ }^{1}$ Cervical cancer is the $4^{\text {th }}$ most common cancer globally and 9 out of 10 of the cases are squamous cell carcinoma type which has worse prognosis. The prevalence of cervical cancer in Indonesia is $20928 .{ }^{2}$ Out of those cases, cervical cancer is responsible for 9498 deaths annually, which makes it the $2^{\text {nd }}$ leading cause of cancer-related death in Indonesia. ${ }^{2}$ Human papillomavirus (HPV) is the known to be the etiology of cervical cancer, especially the high risk strains which are HPV-16 and 18. HPV is considered as a very common virus that can be easily transmitted through sexual contact, regardless of sex. HPV-16 and 18 subtypes are known to be responsible for more than $70 \%$ of the cases. ${ }^{3}$ Screening of pre-cancerous lesion of cervical cancer is done using visual inspection with acetic acid (VIA). This method screens for any abnormal changes on the superficial part of the cervix. This diagnostic method is especially useful to be used low-resource settings such as in primary health care centers in Indonesia. When pre-cancerous lesion is detected, immediate treatment should be done to prevent progression to cancer. ${ }^{4}$ However, the tools and skills to perform VIA or cryotherapy are not evenly distributed and this inspection is subjective as it requires practice and experience in order to correctly perform it. According to the Ministry of Health Indonesia, VIA and breast physical examination as screening efforts to eradicate cervical and breast cancer have been done in 1623913 (3.4\%) women out of 37500000 of total target from 2008 2016. ${ }^{5}$ Moreover, late diagnosis is common as this disease is asymptomatic at its early phases. ${ }^{4}$ Hence, more aggressive treatments with its deleterious side effects need to be applied. In addition to that, these aggressive treatments are only available in some 
health care centers. Thus, due to these conditions, there is an urgent need to develop a new practical, more effective, and less invasive preventive and/or curative effort to beat cervical cancer. G. verrucosa is an edible and relatively cheap seaweed species that can be easily found in Indonesia (Figure 1). Studies have shown that this seaweed has shown promising evidence indicating that extract of $G$. verrucosa is able to induce apoptosis through mitochondrial pathway by involving cytochrome $\mathrm{c}$ release from mitochondria. ${ }^{6}$ Moreover, the species G.tenuistipitata is able to have apoptosis-based cytotoxicity against oral cancer cells by induction of ROS, DNA damage, and mitochondrial depolarization against oral squamous carcinoma displayed by their secondary metabolites. Most studies about Gracilaria seaweeds have been focused on its anti-hypercholesterolemic, anti-oxidative, anti-inflammatory, and antimicrobial properties but not its anti-cancer activities. ${ }^{7}$

Based on this information, we are inspired to evaluate further the anticancer activity of $G$. verrucosa against cervical cancer cells. In this study, we explore the cytotoxic activity of seaweed macro algae G. verrucosa collected from Labuan Aji beach, Lombok, Nusa Tenggara Barat Province, Indonesia. This research utilizes experimental study design to determine the effects of $G$. verrucosa extract against the cervical HeLa cells. This research will be conducted in several stages. The first stage is the collecting and identification of sample G. verrucosa. Next, the sample will be rinse, dry, and grind $G$. verrucosa to give out a smooth, dry powder form. The third stage is to macerate and extract sample G. verrucosa. Then, it will be fractioned into four organic solvents with different polarity which are hexane (non-polar), chloroform (non-polar), ethyl acetate (semi polar), and ethanol (polar). The extracts will undergo serial dilution to produce 8 different concentrations. The HeLa cervical cancer cell line will be nourished, tested for its viability, and incubated first before being treated with any G. verrucosa extract. The last stage is in vitro cytotoxic activity evaluation of hexane, chloroform, ethyl acetate, and ethanol extracts of G. verrucosa against HeLa cervical cancer cells by MTT assay.

In our previous research we have a completed the phytochemistry test and TLC analysis of the seaweed G. verrucosa. Phytochemistry test showed that $G$. verrucosa extract contains metabolite triterpenoid and saponin, whereas TLC analysis of G. verrucosa extract reveals that n-hexane, chloroform solvents showed 7 bands, ethyl acetate solvent showed 6 bands, and ethanol solvent showed 2 bands. This suggests that $n$-hexane, chloroform solvents are non-polar in nature, while ethyl acetate is semi-polar, and ethanol solvent is polar. ${ }^{8}$

\section{METHODS}

\section{Extraction and Fractionation Samples of Seaweeds}

About $1000 \mathrm{~g}$ of dry powder sample of G. verrucosa will be macerated in $500 \mathrm{~mL}$ of separate four organic solvents, namely, n-hexane, chloroform, ethyacetate and ethanol for 7 days inside a sealed vase container while being stirred at some times, 2-3 times a day. Maceration will be done three times to get as many extract as possible. The result of maceration will be filtered and concentrated with rotary evaporator to get $n$-hexane extract $(0.3 \mathrm{~g})$, chloroform extract $(0.2 \mathrm{~g})$, ethylacetate extract $(1 \mathrm{~g})$, and ethanol extract $(1.5 \mathrm{~g})$, respectively. Next, the 4 extracts will be diluted into 5 different concentrations of $3.125 ; 6.25 ; 12.5 ; 25 ; 50 \mu \mathrm{g} / \mathrm{mL}$ by serial dilution method.

\section{In vitro Cytotoxicity Assay}

Malignant HeLa cervical cancer cells taken from the Department of Pathology Anatomy Faculty of Medicine University of Indonesia will be supplemented with $10 \%$ of fetal bovine serum (Gibco, USA) using laminar flow hood technique to ensure sterility. Then it will be cultured into RPMI 1640 (Gibco, USA). The supplemented cultured cells will be incubated in temperature of $37^{\circ} \mathrm{C}$ and $4 \% \mathrm{CO}_{2}$ in a humidified atmosphere. The

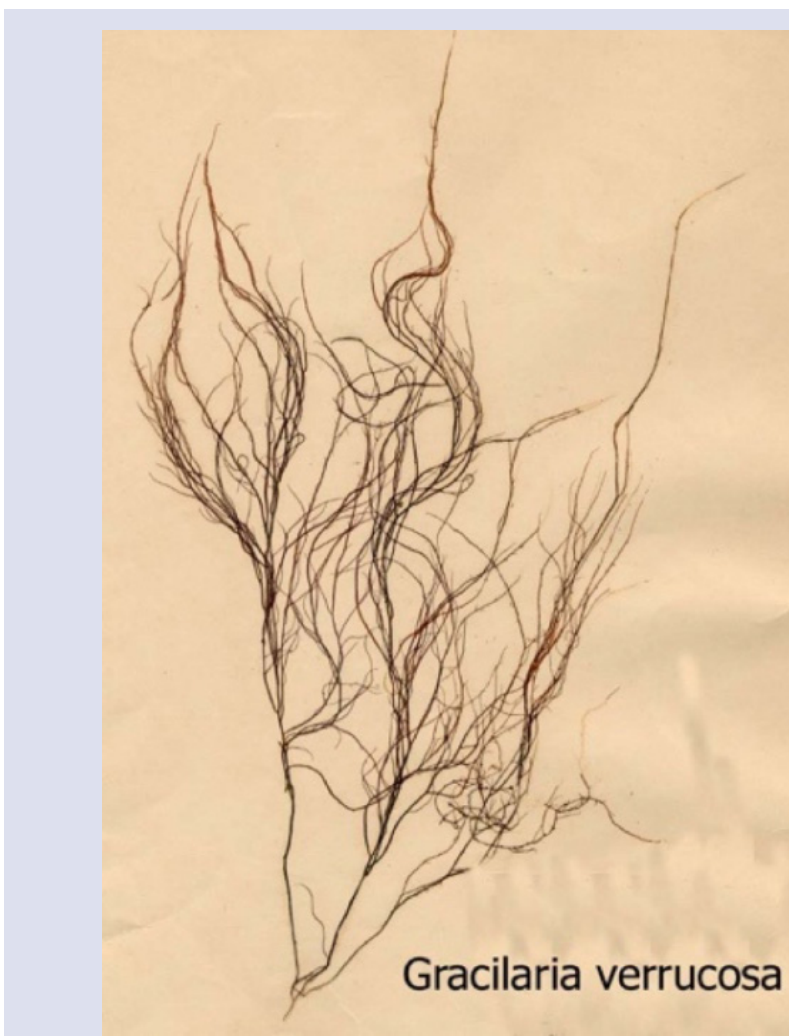

Figure 1: Morphology of Gracilaria verrucosa.

Divisio : Rhodophyta

Classis : Rhodophyceae

Ordo : Gigartinales

Familia : Gracilariaceae

Genus : Gracilaria

Species : Gracilaria verrucosa

viability of cells will be tested using trypan blue $0.1 \%$. If the viability of the cells $>90 \%$, then the cells are able to be used in MTT assay. This is done to avoid inaccuracy in the results of the assay. ${ }^{9}$ The passage cell used here will be passage 5 cell obtained from Department of Pathology Anatomy Faculty of Medicine University of Indonesia.

The next step is to input the cultured cells into 96-microwell with each well containing $10^{4}$ cells. The well will be left overnight to make the cells adhere to the base of the wells. On the next day, the medium will be changed and the cells will be treated with the four extracts of $G$. verrucosa of 5 different concentrations. The treated HeLa cell line will be incubated for 48 hours. Later, an addition of $20 \mu \mathrm{l} 5$ solution $5 \mathrm{mg} / \mathrm{mL}$ MTT phosphate-buffered saline (PBS) will be added into the wells. The mixture inside the plates are incubated for 4 hours, then it will be centrifuged and separated from its medium. About $20 \mu \mathrm{DMSO}$ is added into every well so that it will dissolve a blue purple sediment. Absorbance is measured in $590 \mathrm{~nm}$ on a microplate reader (Model 550, Bio-Rad, USA). ${ }^{9-10}$ Inhibitory activity of the extracts are measured using the following formula.

$$
\text { \%Inhibition }=1-\left(\frac{\text { absorbance of treatment group }}{\text { absorbance of control group }}\right) \times 100 \%
$$

$\mathrm{IC}_{50}$ is calculated using Microsoft Excel 2013 by connecting the G. verrucosa extract concentration (x-axis) and the percent inhibition (y-axis), from which a linear equation was then created. 


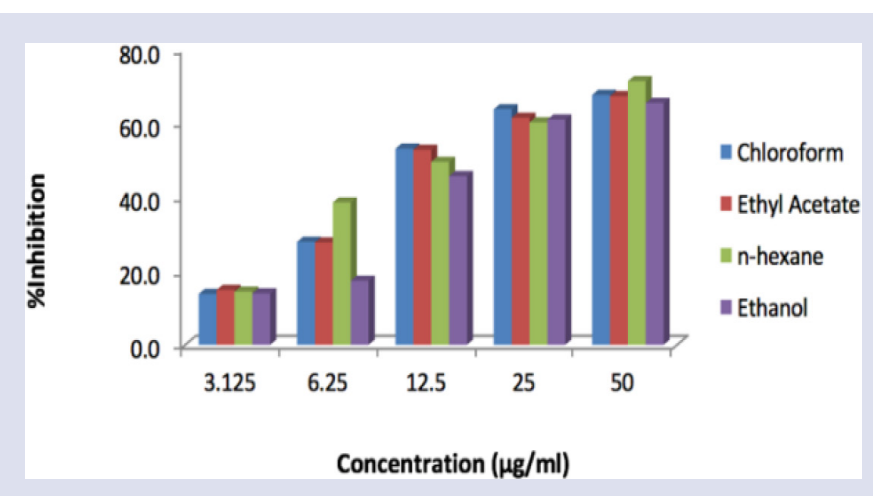

Figure 2: The relationship between relative concentrations of an extract and their percentage inhibition towards cervical HeLa cells.

Table 3: $\mathrm{IC}_{50}$ values of Gracilaria verrucosa extracts on HeLa cells.

\begin{tabular}{cc}
\hline Tested extract & $\mathrm{IC}_{50}(\mu \mathrm{g} / \mathrm{mL})^{*}$ \\
\hline Gracilaria verrucosa & $\mathrm{HeLa}$ \\
Hexane & $14.94 \pm 7.19$ \\
Chloroform & $15.74 \pm 0.64$ \\
Ethyl acetate & $16.18 \pm 0.66$ \\
Ethanol & $19.43 \pm 2.72$ \\
\hline
\end{tabular}

${ }^{\star} \mathrm{IC}_{50}$ is the $50 \%$ half maximal inhibitory activity in $\mu \mathrm{g} / \mathrm{mL}$, expressed in mean value $(\mathrm{n}=3)+\mathrm{SD}$. ${ }^{\star S D}$ : Standard deviation.

\section{RESULTS}

\section{Cytotoxic Activity of Seaweeds G. verrucosa}

Figure 2 shows the percentage inhibition of all G. verrucosa extracts ranges from $13.8-71.4 \%$ against cervical HeLa cells. Based on linear equation $\mathrm{IC}_{50}$ all extract has small $\mathrm{IC}_{50}$ under $20 \mu \mathrm{g} / \mathrm{mL}$. Hexane extract of $G$. verrucosa showed the greatest anticancer activity compared to others, they are shown on Table 3.

\section{DISCUSSION}

\section{Cytotoxic Activity of Seaweeds G. verrucosa}

Cytotoxic activity is depicted by $\mathrm{IC}_{50}$ value. The lower the $\mathrm{IC}_{50}$ value of an extract, the greater the anticancer exhibited, while, percentage inhibition tells how well the extract can inhibit the cancer cell growth. The higher percentage inhibition is; the greater inhibition is shown by the sample towards cell growth. Figure 2 displays the percentage inhibitory activity and the concentration of the extract towards cervical HeLa cells. The results indicate that percentage inhibition and relative concentration of the extract is directly proportional. Which means, all of the four extracts are concentration-dependent in terms of inhibiting the growth of $\mathrm{HeLa}$ cells. Anticancer activity of G. verrucosa is depicted by $\mathrm{IC}_{50}$ value $(\mu \mathrm{g} / \mathrm{mL})$. anticancer activity level of the extracts are categorized according to the median inhibitory concentration $\left(\mathrm{IC}_{50}\right)$ into four groups: $\leq 20 \mu \mathrm{g} / \mathrm{mL}$, active; $>20-100 \mu \mathrm{g} / \mathrm{mL}$, moderately active; $>100-1000 \mu \mathrm{g} / \mathrm{mL}$, weakly active; and $>1000 \mu \mathrm{g} / \mathrm{mL}$, inactive. ${ }^{11}$ As displayed in Table 2, the $\mathrm{IC}_{50}$ value of all extracts are less than 20 , this means that all of $G$. verrucosa extracts are active in inhibiting the growth of cervical HeLa cells. The most effective extract is hexane extract, as it has the smallest $\mathrm{IC}_{50}$ compared to other extracts. This means that it only requires a small amount of hexane extract of G. verrucosa to be able to inhibit $50 \%$ of cervical HeLa cells. This result proves that G. verrucosa has a big potential on becoming anti-cervical cancer drug.

The main objective of making 4 different extracts of G. verrucosa in different solvents of varying polarity is to determine at which polarity, the secondary metabolites of seaweed G. verrucosa work best in inhibiting the growth of HeLa cervical cancer cells. Secondary metabolites of seaweed vary in their degree of polarity, and the presence of those secondary metabolites can be evaluated through several methods such as phytochemical analysis and thin layer chromatography. The principle is, compounds are dissolved according to the polarity of their solvent. Polar compounds are more likely to be dissolved in polar solvents, while non polar compounds are more likely to be dissolved in non polar solvents. ${ }^{12}$ The polarity, concentration, and physiochemical characteristics of solvents will affect the activity of bioactive compounds present in the seaweed..$^{13}$ A study done in Jakarta, Indonesia performed phytochemical analysis on seaweed $G$. verrucosa which also comes from the same habitat studied here. The phytochemical result was positive for saponin and triterpenoid. ${ }^{8}$ The presence of triterpenoid and saponin in chloroform, hexane, ethanol, and ethyl acetate extract might be the reason why seaweed G. verrucosa is able to inhibit the growth of HeLa cervical cancer cells. ${ }^{8}$ Triterpenoid has nonpolar characteristic and dissolved better in a nonpolar solvent such as hexane and chloroform, thus it can be concluded that the most dominant secondary metabolite in inhibiting the growth of HeLa cervical cancer cells is triterpenoid rather than saponin. ${ }^{12}$ However, this does not mean that the secondary metabolite of saponin is inactive against HeLa cervical cancer cells, because the ethanol also shown anticancer activity towards HeLa cervical cell line. ${ }^{14}$

Both triterpenoid and saponin have pro-apoptotic activities towards cancer cells by the following suggested mechanisms; alteration of mitochondrial membrane potential, initiation of calcium-dependent apoptosis, or induction of cell cycle arrest. ${ }^{15-17}$ Moreover, triterpenoid and saponin derivatives are known to have inhibitory effects to the growth of cervical cancer cells. ${ }^{18-20}$

\section{CONCLUSION}

Our results clearly demonstrate that seaweed G. verrucosa can be further developed to be an anti-cervical cancer drug.

\section{ACKNOWLEDGEMENT}

We wish to express our gratitude to Directorate of research and Public Service University of Indonesia for PITTA (Publikasi International Terindeks Scopus Untuk Tugas Akhir Mahasiswa) research grant fiscal year 2017.

\section{CONFLICT OF INTEREST}

The authors declare no conflict of interest.

\section{ABBREVIATIONS}

MTT: (3-(4,5-Dimethylthiazol-2-yl)-2,5-Diphenyltetrazolium Bromide); IC $_{50}$ : Inhibition Concentration 50\%; \%: Percentage; $\mathbf{4}^{\text {th }}$ : Fourth; $\mathbf{K m}^{2}$ : Kilometer Square; ROS: Reactive oxygen Species; DNA: Deoxyribosenucleic acid; $\mu$ g: Microgram; nm: Nanometer; g: Gram; mL: Millimeter; N: Normality; cm: Centimeter; RPMI: Rosewell Park Memorial Institute; PBS: Phosphate- Buffered Saline; HeLa: Henrietta Lack ; C: Degree Celsius; $\mu \mathrm{l}$ : Microliter; $\mathrm{CO}_{2}$ : Carbon dioxide; $\mu \mathrm{g} / \mathrm{mL}$ : Microgram $/ \mathrm{milliliter}$.

\section{REFERENCES}

\footnotetext{
1. Cervical cancer - NHS Choices [Internet]. Nhs.uk. 2017 [cited 18 June 2017] Available from: http://www.nhs.uk/Conditions/Cancer-of-the-cervix/Pages/Introduction.aspx
} 
2. Human Papillomavirus and Related Diseases Report [Internet]. HPV Centre. 2017 [cited 18 June 2017]. Available from: http://www.hpvcentre.net/statistics/ reports/IDN.pdf

3. Vinay K, Abul K. Abbas, Jon CA. Female Genital System and Breast. In: Robbins basic pathology. $10^{\text {th }}$ ed. Philadelphia, Pennsylvania: Elsevier. 2018:713-47.

4. Comprehensive Cervical Cancer Control - A guide to essential practice [Internet]. World Health Organization. 2017 [cited 20 June 2017]. Available from: http://apps.who.int/iris/bitstream/10665/144785/1/9789241548953_eng.pdf

5. Kementerian Kesehatan Republik Indonesia [Internet]. Depkes.go.id. 2018 [cited 26 June 2018]. Available from: http://www.depkes.go.id/article/ print/16111800002/ratusan-pegawai-perempuan-kemenkes-lakukan-deteksidini-kanker.html

6. Fitria M, Warganegara F. Aqueous-Methanol Extract of Gracilaria verrucosa Induces Cytochrome c Release From Mitochondria. Procedia Chemistry. 2015; 16:407-412.

7. Yeh C, Yang J, Lee J, Tseng C, Chan Y, Hseu Y, et al. Anti-proliferative effect of methanolic extract of Gracilaria tenuistipitata on oral cancer cells involves apoptosis, DNA damage, and oxidative stress. BMC Complementary and Alternative Medicine. 2012;12(1).

8. Kartika DK, Ade A, Yully ANA, Baiq KDM, Riathul M, Futihati RZ, et al. Phytochemical analysis and anticancer activity of seaweed Gracilaria verrucosa against colorectal HCT-116 cells. Oriental Journal of Chemistry. 2018;34(3).

9. Bowey-Dellinger K, Dixon L, Ackerman K, Vigueira C, Suh YK, Lyda T, et al. Introducing Mammalian Cell Culture and Cell Viability Techniques in the Undergraduate Biology Laboratory †. JMBE [Internet]. 2017 Aug 31 [cited 2018 Jun 27];18(2). Available from: http://www.asmscience.org/content/journal/ jmbe/10.1128/jmbe.v18i2.1264

10. Riss TL, Moravec RA, Niles AL, Sarah D, Hélène AB, Tracy JW, et al. Cell Viability Assays. 2013 May 1 [Updated 2016 Jul 1]. In: Sittampalam GS, Coussens NP, Brimacombe K, et al. editors. Assay Guidance Manual [Internet]. Bethesda (MD): Eli Lilly and Company and the National Center for Advancing Translational Sciences; 2004-. Available from: https://www.ncbi.nlm.nih.gov/
books/NBK144065/

11. Atjanasuppat K. Wongkham W, Meepowpan P, Kittakoop P, Sobhon P, Bartlett A, et al. In vitro screening for anthelmintic and antitumour activity of ethnomedicinal plants from Thailand. J Ethnopharmacol. 2009;123(3):475-82.

12. Ragaya $A B$, Yayuk $A$, Erin RG. Analisis senyawa triterpenoid dari hasil fraksinasi ekstrak air buah buncis (Phaseolus vulgaris Linn). Universitas Sam Ratulangi Chemistry Progress. 2013;6(2):45-91.

13. Cyril R, Lakshmanan R, Thiyagarajan A. In vitro bioactivity and phytochemical analysis of two marine macro-algae. Journal of Coastal Life Medicine. 2017; 5(10):427-32

14. Paini SW, Tarsisius DWB, Fenny AK, Evelyn LV. Difference of solvent polarity to phytochemical content and antioxidant activity of pluchea indicia less leaves extracts. IJPPR. 2014;6(4):850-5

15. Saponins [Internet]. Phytochemicals.info. 2017 [cited 2 August 2017]. Available from: http://www.phytochemicals.info/phytochemicals/saponins.php

16. Man S, Gao W, Zhang Y, Huang L, Liu C. Chemical study and medical application of saponins as anti-cancer agents. Fitoterapia. 2010;81(7):703-14.

17. Patlolla JMR, V. Rao C. Triterpenoids for Cancer Prevention and Treatment: Current Status and Future Prospects. Current Pharmaceutical Biotechnology 2012;13(1):147-55

18. Rzeski W, Stepulak A, Szymanski M, Sifringer M, Kaczor J, Wejksza K, et al. Betulinic acid decreases expression of bcl-2 and cyclin D1, inhibits proliferation, migration and induces apoptosis in cancer cells. Naunyn-Schmiedeberg's Archives of Pharmacology. 2006;374(1):11-20

19. Amini E, Nabiuni M, Baharara J, Parivar K, Asili J. In-vitro pro apoptotic effect of crude saponin from Ophiocoma erinaceus against cervical cancer. Iran J Pharm Res. 2017;16(1):266-76

20. Zhang W, Zhang D, Ma X, Liu Z, Li F, Wu D. Paris saponin VII suppressed the growth of human cervical cancer Hela cells. European Journal of Medical Research. 2014:19(1):41.

\section{GRAPHICAL ABSTRACT}

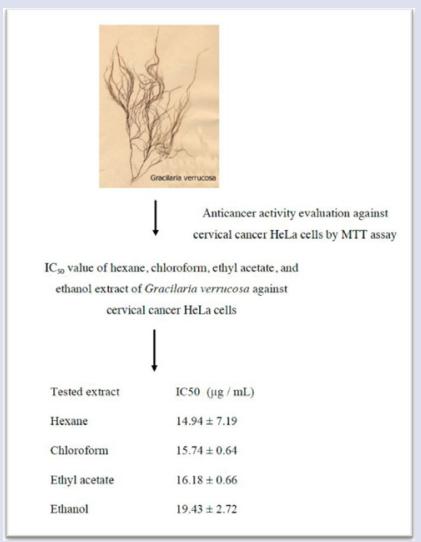

\section{SUMMARY}

- G. verrucosa originated from Labuan Aji beach, Nusa Tenggara Barat, Indonesia, exhibited cytotoxicity against HeLa cells with $\mathrm{IC}_{50}$ ranging from $14.94 \mu \mathrm{g} /$ $\mathrm{mL}$ to $19.43 \mu \mathrm{g} / \mathrm{mL}$.

\section{ABOUT AUTHORS}

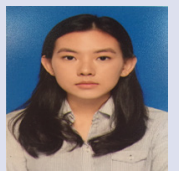

Micheylla Kusumaning Dewi: Medical Student, Faculty of Medicine, Universitas Indonesia. Research interest in Herbal Medicine, Cancer Biology, Pediatric Diseases

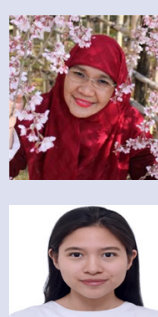

Ade Arsianti: Lecturer and Researcher at Medical Chemistry and Drug Development Research Center Indonesian Medical Education and Research Institute, Faculty of Medicine, Universitas Indonesia. Research interest: Medicinal chemistry, Synthetic Organic Chemistry and Natural Product Chemistry.

Cut Raisya Zahira Zagloel: Medical Student, Faculty of Medicine, Universitas Indonesia. Research interest in Woman and Pediatrics Cancer.

1.

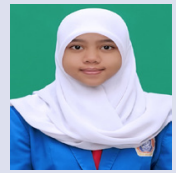

Yully Astika Nugrahayning Aziza: Medical student, Faculty of Medicine Universitas Indonesia. Research interest: Herbal Medicine, Cancer Biology 


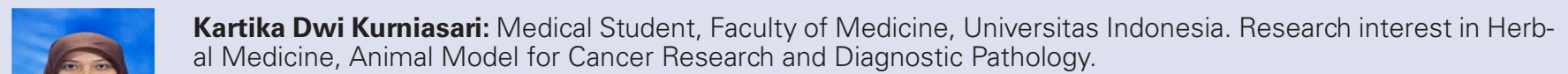

al Medicine, Animal Model for Cancer Research and Diagnostic Pathology.

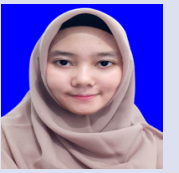

Baiq Kirana Dyahningrum Mandasari: Medical Student, Faculty of Medicine Universitas Indonesia Research interest in Endorinology and Metabolic disease, Cardiology, Vascular Surgery, Cancer Biology, Immunology, Oncology, Pediatric Disease.

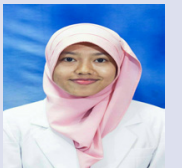

Riathul Masita: Medical Student, Faculty of Medicine University of Indonesia. Reseacrh interest in Tissue Culture and Analytical Chemistry.

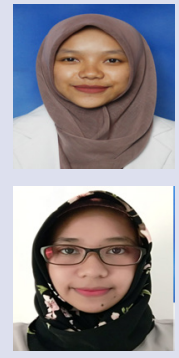

Futihati Ruhama Zulfa: Medical Student, Faculty of Medicine Universitas Indonesia Research interest : Cardiology, pulmonology, Endocrinology and Metabolic disease, Cancer Biology, Oncology, urology.

Norma Nur Azizah, S.Si: Researcher at Drug Development Research Center, Indonesian Medical Education and Research Institute, Faculty of Medicine, Universitas Indonesia. Research interest tissue culture, analytical chemistry, and natural product chemistry in drug development.

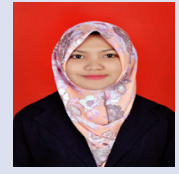

Rista Putrianingsih, S.T: Researcher at Medical Chemistry, Faculty of Medicine, Universitas Indonesia. Research interest tissue culture and natural product chemistry.

Cite this article: Dewi MK, Arsianti A, Zagloel CRZ, Aziza YAN, Kurniasari KD, Mandasari BKD, Masita R, Zulfa FR, Azizah NN, Putrianingsih R. In vitro Evaluation of Seaweed Gracilaria verrucosa for Cytotoxic Activity against Cervical HeLa Cells. Pharmacog J. 2018;10(5):1007-11. 